\title{
"Making It Worse than What Really Happened": Social Chaos and Preparedness as Problematic Mythologies in Disaster Communication
}

\author{
Natalie D. Baker* \\ Virginia Commonwealth University, Richmond, VA, USA
}

OPEN ACCESS

Edited by:

Douglas Paton,

Charles Darwin University, Australia

Reviewed by:

Fatih Demiroz,

Sam Houston State University, USA

Yingying Sun,

Kyoto University, Japan

${ }^{*}$ Correspondence:

Natalie D. Baker

nbaker2@vcu.edu

Specialty section: This article was submitted to Disaster Communications,

a section of the journal

Frontiers in Communication

Received: 27 January 2016 Accepted: 25 April 2016

Published: 10 May 2016

Citation:

Baker ND (2016) "Making It Worse than What Really Happened": Social

Chaos and Preparedness as

Problematic Mythologies in Disaster Communication.

Front. Commun. 1:2.

doi: 10.3389/fcomm.2016.00002
This perspective piece explores both social chaos and disaster preparedness as mythologies that are a persistent part of problems with disaster communication. It argues that while extant scholarship acknowledges disaster myths that advance the belief that social chaos and, for example, looting is common is problematic, there has not been much done to mitigate this in practice. Furthermore, the continued focus on social disorder in institutional efforts does not recognize inherent skills and capabilities of citizens both at risk for and affected by disaster. Here, I argue that the concept of preparedness is an expectation that dichotomizes human behavior and is a form of social control. Those who are not prepared according to institutional norms have the potential to be unruly. The management of large emergencies must mitigate myths and advance more accurate understandings of prosociality in disasters. To this end, the status quo communicates bad information about human behavior in crisis that perpetuates a paternalistic institutional approach that stagnates equitable disaster management. Here, I pose a call for new directions in disaster research given such issues.

Keywords: disaster myths, disaster management, disaster communication, social chaos, disaster preparedness, social control

On September 11th, 2001, as hundreds of thousands fled south from the burning towers, people quickly discovered something we often forget: that Manhattan is an island. As officials closed all bridges, tunnels and commuter lines linking Manhattan to the rest of the world, people were trapped. The little told story of what happened next is the focus of my documentary short film, BOATLIFT, narrated by Tom Hanks. The film premiered at the Center for National Policy's 9/11 Ten Year Anniversary Summit, in Washington, D.C. BOATLIFT is the story of the largest maritime evacuation in history. On $9 / 11$, over 500,000 people were rescued from Manhattan's seawalls in just nine hours. How did this happen? What heroism made this possible? The answer lies in the resilience of the everyday people at the scene that day, and the brave community of mariners who ply the waters of New York's Harbor (Rosenstein, 2011).

After the terrorist attacks of September 11, 2001, the massive boatlift described in the selection from the Huffington Post above was spontaneously organized by both mariners and officials who 
were determined to get people off Manhattan. This film shows some pretty remarkable, but also common actions undertaken by mostly ordinary citizens in the aftermath of disaster. BOATLIFT provides evidence, at least in this instance, that social chaos was not characteristic of public response after the attacks. Despite such prosocial acts documented during 9-11 by some scholars [see Wachtendorf (2004) and Wachtendorf and Kendra (2006)] and in the BOATLIFT documentary, treatment by politicians and media focused on the sensationalistic elements of this horrific event. This galvanized a collective sense of nationalism, rather than a focus on heroism. Why did we not hear about the boatlift in news after the attacks?

Similarly, the post-Katrina aftermath and response by citizens was positioned as social chaos by politicians, media, and even victims. Here, we heard much about depraved conditions, particularly among the most disadvantaged:

Appearing on "Oprah" on Sept. 6. Chief Eddie Compass said of the Superdome: "We had little babies in there, some of the little babies getting raped." Mayor C. Ray Nagin concurred: "They have people standing out there, have been in the frickin' Superdome for five days watching dead bodies, watching hooligans killing people, raping people." But the night before, Chief Compass had told The Guardian, "We don't have any substantiated rapes. We will investigate if they come forward." Many of the more toxic rumors seem to have come from evacuees, half-crazed with fear sitting through night after night in the dark. Victims, officials, and reporters all took one of the most horrific events in American history and made it worse than it actually was. Although I was not in New Orleans, I was at the World Trade Center towers site the afternoon of Sept. 11, 2001. People had seen unimaginable things, but a small percentage, many still covered in ash, told me tales that were worse than what actually happened. Mothers throwing babies out of the towers, men getting in fights on the ledges, human heads getting blown out of the buildings, all of which took place so high up in the air that it was hard to distinguish the falling humans from the falling wreckage (Carr, 2005).

As alluded to in the selection above, the portrayal of human behavior in disasters such as Katrina, and even 9-11, as chaotic, violent, animalist, barbaric, and so on [see Tyson (2005), for example] are greatly exaggerated and/or patently false (Tierney et al., 2006; Sun, 2011, 2012). Yet, during both 9-11 and Katrina, publics and institutions were preoccupied with the spectacle and drama of these disasters. While the attack in New York was very real, so was the boatlift. On the other hand, looting reported during Katrina was arguably imagined (Tierney et al., 2006), but actions such as citizenbased rescues, even among the poor Blacks of the city who were likened to animals, hooligans, and thugs were also very real (Rodriguez et al., 2006). The federal response to Hurricane Katrina in direct relationship to the reports of chaos resulted in rescue-based efforts being suspended for more combat-like approaches to response where everyday citizens were held at gunpoint by members of their own military. One only need look to the Posse Comitatus Act, which forbids policing actions of most military with regard to the US public (Greenberger and Spaccarelli, 2010) to understand such actions as problematic. Yes, during Katrina, a particular selection of American citizens was treated as enemy combatants by members of the military. It is the duty of disaster scholars and managers to make sure this never happens again, and continue to ask what it is about US society that permitted this.

One answer is that societal projections of social chaos in disasters through mediums, such as Hollywood, news, rumors, and exaggerations, advance the idea that this is a fundamental feature of such events. Such medium advances the notion that publics are unruly. I do not suggest they cause mythologies to perpetuate rather they reflect and constitute them. As one of my research participants in an on-going and not-yet-published project on journalists in hostile environments puts it, "we are the media and the media is us." Thus, American society bears some responsibility because of preferences, values, and practices embedded within these outputs. For example, hyperbolic portrayals of threat sell stories about large-scale disasters or potential crises that tap into societal values such as nationalism (Baker et al., 2015) or resonate with a preference for narratives of "good versus evil" (Cottle, 2006). Indeed, the structure of the post-9-11 emergency management system is headed to a more militarized form (Tierney and Bevc, 2007; Masco, 2014; Sun and Jones, 2015), where dealing with the imagined threat of a "bad" unruly populace is a major priority to be dealt with by "good" management systems, even though this is largely mythological. Disaster institutions have bought into, and perpetuate these mythologies.

Here, I am explicit in putting forward the dangers of the continued advancement of such misunderstandings of human behavior in the midst of crisis because it both contradicts knowledge about response and creates room for marginalization as seen in Katrina. We know that people respond in flexible (Baker et al., 2012), improvisational (Wachtendorf, 2004; Kendra and Wachtendorf, 2006), and ultimately prosocial ways (Solnit, 2010) during crisis events. People have the capacity to organize and act heroically in the absence of formal plans, or emergency responders [see, for example, Dynes (1990)]. It has even been suggested that emergent, prosocial behavior without preparation is equally as important planning and preparedness activities (Kendra and Wachtendorf, 2006) advanced by management institutions as fundamental to response. Yet, the institution of disaster management continues to treat publics either as threats, or complacent despite much evidence to the contrary. The institutional norm of preparedness partly advances such notions of the public. This is explained in detail below.

The current state of mainstream disaster research and practice, with some exception, tends to focus on the creation of a "preparedness culture" to ensure populations at risk are able to respond in disasters. On the surface, preparedness is a way that publics can take personal responsibility for building resilience in response to the potentiality of crisis (Paton, 2001, 2003; Tierney et al., 2001), aid in recovery (Diekman et al., 2007), and decrease vulnerability 
(Becker et al., 2012, 2013). Preparedness is built on an assumption that if people prepare they should be able to "bounce back" after a disaster. But is this really the case?

There are some scholars who question the above assumption. For example, Baker (2014a,b) argues the expectation of preparedness idealizes compliance to institutional preparedness directives (e.g., collecting supplies and making plans), whereas public reflections demonstrate self-organization and prosociality. Thus, people have problems engaging in preparedness efforts as told because (1) the notion of an impending disaster does not fit in with their experience of reality as stable and (2) they have confidence in their ability to make it through a disaster despite a lack of preparedness efforts. For the most part, they trust their existing skills, abilities, and resources to help them recover in even the most disruptive situations (Baker, 2014a). However, the belief that vulnerable publics can take matters in their own hands in the instance of disaster without previous preparation, is threatening to emergency management.

Recent research suggests that the institutional notion of disaster preparedness, while indeed intended to help keep people safe, is also about controlling publics which are viewed as potential threats. Baker and Grant Ludwig (2016) theorize based on empirical research that preparedness is an expectation embedded within the militarizing structures of US emergency management and is a form of social control. Preparedness, as a concept, is built on an assumption that the creation of plans and collection of supplies is necessary to "bounce back," whereas at-risk publics tend to believe they can respond in the immediacy of the moment. The fact that people negotiate disasters through adaptation and without preparedness has been established in extant scholarship. When confronted with this, emergency management becomes uncomfortable. Baker and Grant Ludwig (2016) show unprepared publics that trust their ability respond are viewed threatening, prone to panic, and ultimately a source of social chaos. A prepared public is compliant, safe, and controlled. A public that responds to the immediacy of the situation, as is natural, is a source of "social chaos" that disaster management institutions fear, but also require to perpetuate their very existence. If it is the case that publics are perpetuated as unruly threats through mythology, is the prepared public according to institutional standards also a myth? I argue this is a major roadblock to equitable disaster management and communication efforts, as well as the mitigation of disaster mythology.

\section{CONCLUSION}

Preparedness is an almost universal expectation in emergency management. But as Evans and Reid (2014), p. 10, warn, "Be deeply suspicious of anything that masks itself in universal regalia. Bring into question that which is not being questioned in the normal state of affairs." This is our task to take to heart if we really want to advance our collective understandings of disasters. Much of the current state of disaster research and emergency management practice, particularly in the area of preparedness, dichotomizes behavior into categories such as "prepared or not." It is an easy leap from not prepared, to complacent, and then to unruly, particularly for those populations who are already pigeonholed as such (e.g., black, poor New Orleanians during Katrina). These dichotomizations both stagnate progress and create spaces for inequity and myth. Furthermore, social scientists know that the world of human behavior is incredibly dynamic and nuanced. Such black and white conceptualizations contradict what we see in response efforts on the ground in many disaster cases. Context matters deeply, yet is virtually ignored in the emergency management world.

The problematizations I pose are rooted in issues of the communication of mythologies and expectations of disaster management institutions. How then can human communication be improved in the advancement of better, particularly more equitable disaster management? Furthermore, we should ask, what does better disaster management mean if we destroy or take into question our myths and universals? Unfortunately, I do not have these answers. As a social scientist, one of the issues that keeps me employed is that human beings are messy. Perhaps the better question to ask is what are the new problems we can work on together, outside of what is currently being done?

One-dimensional approaches to disasters that advance the idea of preparedness as the absolute answer to successful responses, whatever that means, feed into the assumptions that publics are apathetic, threatening, and or helpless. We must take to task why there is an almost religious belief that preparedness is the key to successful response. We must provide clear causal links between preparedness efforts and successful response, or study why this is advanced as the only answer. If there are weak connections, we need to research the context of disasters, rather than how to make people prepare better. We need to ask and understand how we can allow for the potential that clearly exists in most everyone to grow, rather than ignore or punish it in the case of a lack of adherence to institutional directives. The first step is to explicitly acknowledge our inherent problems with both expectations and communication, as in the case of a continued perpetuation of disaster myths such as lawlessness or panicked publics that evoke a need to "govern," but actually bloat understandings of human behavioral response realities as worse than they actually are. It is our collective task as those invested in the management of crisis to understand, identify, and draw upon the potentials of the public in the advancement of more human, equitable disaster negotiation rather than uphold a paternalistic status quo rife with problems and anti-democratic approaches. We will experience more boatlifts in the future.

\section{AUTHOR CONTRIBUTIONS}

$\mathrm{NB}$ was the sole author of this paper. As this is a perspective paper, it is the opinion/ideas of the author based on the body of her research. 


\section{REFERENCES}

Baker, N. D. (2014a). Potential improvisations: the role of explicit and implicit practices in the production of situated preparedness for disasters. Nat. Hazards Rev. 15:05014002. doi:10.1061/(ASCE)NH.1527-6996.0000127

Baker, N. D. (2014b). 'Everything Always Works': disaster preparedness as construction of the 'risk society'. Int. J. Mass Emerg. Disasters 32, 428-458.

Baker, N. D., Feldman, M. S., and Lowerson, V. (2012). Working through disaster: re-establishing mental health care after Hurricane Katrina. Disaster Med. Public Health Prep. 6, 311-315. doi: 10.1001/dmp.2012.12

Baker, N. D., and Grant Ludwig, L. (2016). Disaster preparedness as social control. Critical Policy Studies. (in press).

Baker, N. D., Samonas, S., and Artello, K. (2015). “(Not) Welcome to the US: Hyper-Ebola and the Crisis of Misinformation', short paper, ethical, legal and social issues," in Proceedings of the ISCRAM 2015 Conference, eds L.Palen, M.Büscher, T.Comes, and A.Hughes (Kristiansand).

Becker, J. S., Paton, D., Johnston, D. M., and Ronan, K. R. (2012). A model of household preparedness for earthquakes: how individuals make meaning of earthquake information and how this influences preparedness. Nat. Hazards 64, 107-137. doi:10.1007/s11069-012-0238-x

Becker, J. S., Paton, D., Johnston, D. M., and Ronan, K. R. (2013). Salient beliefs about earthquake hazards and household preparedness. Risk Anal. 33, 1710-1727. doi:10.1111/risa.12014

Carr, D. (2005). More horrible than the truth: news reports. New York Times. Available at: http://www.nytimes.com/2005/09/19/business/media/more-horrible-than-truth-news-reports.html?_r=0 (accessed $18 \mathrm{Jan}, 2016)$.

Cottle, S. (2006). Mediatized Conflict: Developments in Media and Conflict Studies. Maidenhead: Open University Press.

Diekman, S. T., Kearney, S. P., O’Neil, M. E., and Mack, K. A. (2007). Qualitative study of homeowners' emergency preparedness: experiences, perceptions, and practices. Prehosp. Disaster Med. 22, 494-501. doi:10.1017/ S1049023X00005318

Dynes, R. R. (1990). Community Emergency Planning: False Assumptions and Inappropriate Analogies. Newark: University of Delaware Disaster Research Center. Preliminary Paper \#145.

Evans, B., and Reid, J. (2014). Resilient Life: The Art of Living Dangerously. Cambridge: Polity Press.

Greenberger, M., and Spaccarelli, A. (2010). "The Posse Comitatus Act and disaster response," in Homeland Security and Emergency Management: A Legal Guide for State and Local Governments, 2nd Edn, Vol. 2010, eds E. B.Abbott and O. J.Hetzel (Chicago: American Bar Association, Section of State and Local Government Law), 41-60. Available at: http://www.abanet.org/abastore/index. $\mathrm{cfm} ?$ section $=$ main $\& \mathrm{fm}=$ Product.AddToCart $\pi \mathrm{d}=5330210$

Kendra, J., and Wachtendorf, T. (2006). Improvisation, Creativity, and the Art of Emergency Management. University of Delaware, Disaster Research Center. Preliminary Paper \#375.

Masco, J. (2014). The Theater of Operations: National Security Affect from the Cold War to the War on Terror. Durham: Duke University Press.

Paton, D. (2001). Disasters and communities: vulnerability, resilience, and preparedness. Disaster Prev. Manag. 10,270-277. doi:10.1108/EUM0000000005930
Paton, D. (2003). Disaster preparedness: a social-cognitive perspective. Disaster Prev. Manag. 12, 210-216. doi:10.1108/09653560310480686

Rodriguez, H., Trainor, J., and Quarantelli, E. L. (2006). Rising to the challenges of a catastrophe: the emergent and prosocial behavior following Hurricane Katrina. Ann. Am. Acad. Pol. Soc. Sci. 604, 82-101. doi:10.1177/0002716205284677

Rosenstein, E. (2011). Tom Hanks narrates 'Boatlift' honors untold story of mariner heroes. Huffington Post. Available at: http://www.huffingtonpost. com/eddie-rosenstein/tom-hanks-narrates-boatlift_b_956529.html (accessed 15 Jan, 2016).

Solnit, R. (2010). A Paradise Built in Hell: The Extraordinary Communities that Arise in Disaster. New York: Penguin Books.

Sun, L. G. (2011). Disaster mythology and the law. Cornell Law Rev. 96, 1131-1208.

Sun, L. G. (2012). Disaster mythology and availability cascades. Duke Envtl. L. \& Poly F, Vol. 23, 73.

Sun, L. G., and Jones, R. A. (2015). "War rhetoric and disaster transparency," in Risk Analysis of Natural Hazards: Interdisciplinary Challenges and Integrated Solutions, eds P.Gardoni, C.Murphy, and A.Rowell (Heidlelberg: Springer), 199-219.

Tierney, K., and Bevc, C. (2007). "Disasters as war: militarism and the social construction of disaster in New Orleans," in The Sociology of Katrina: Perspectives on a Modern Catastrophe, eds D. L.Brunsma, D.Overfelt, and S. J.Picou (Lanham: Rowman and Littlefield), 35-50.

Tierney, K. J., Bevc, C., and Kuligowski, E. (2006). Metaphors matter: disaster myths, media frames, and their consequences in Hurricane Katrina. Ann. Am. Acad. Polit. Soc. Sci. 604, 57-81. doi:10.1177/0002716205285589

Tierney, K. J., Lindell, M., and Perry, R. (2001). Facing the Unexpected: Disaster Preparedness and Response in the United States. Washington, DC: Joseph Henry Press.

Tyson, A. (2005). Troops back from Iraq find another war zone in New Orleans, "It's like Baghdad on a Bad Day". The Washington Post, 6th September, A10.

Wachtendorf, T. (2004). Improvising 9-11: Organizational Improvisation Following the World Trade Center Disaster. Doctoral dissertation, University of Delaware Press, Newark.

Wachtendorf, T., and Kendra, J. (2006). Improvising Disaster in the City of Jazz: Organizational Response to Hurricane Katrina. Social Science Research Council. Available at: http://understanding Katrina.ssrc.org/Wachtendorf-Kendra/ printable.html

Conflict of Interest Statement: The author declares that the research was conducted in the absence of any commercial or financial relationships that could be construed as a potential conflict of interest.

Copyright $\odot 2016$ Baker. This is an open-access article distributed under the terms of the Creative Commons Attribution License (CC BY). The use, distribution or reproduction in other forums is permitted, provided the original author(s) or licensor are credited and that the original publication in this journal is cited, in accordance with accepted academic practice. No use, distribution or reproduction is permitted which does not comply with these terms. 